\title{
Research Article \\ Impact of Covid-19 on Tourism Business in Pokhara Nepal
}

\author{
${ }^{1}$ Shreekanta S. Khatiwada*, ${ }^{2}$ Ramji Sharma, ${ }^{3}$ Suresh Ranabhat \\ ${ }^{1}$ Lecturer, Institute of Forestry, Tribhuvan University and PhD Scholar of Singhaniya \\ University, Rajasthan, India \\ ${ }^{2}$ Asst. Professor at Pokhara Lincoln International College, Lincoln University \\ ${ }^{3}$ Lecturer, Janapriya Multiple Campus, Pokhara, Nepal \\ *Corresponding email: skkhatiwada@gmail.com
}

\author{
Article History \\ Received 22 May 2021 \\ Revised 6 October 2021 \\ Accepted 7 November 2021
}

\begin{abstract}
None of the sectors in human society is out of the assault of covid-19 pandemic. Every sphere of human life is affected by this contagion virus nonetheless the severity of influence and impact may vary Tourism is one of the highly injured sectors during on-covid period and so as the situation of Pokhara and its vicinity. This paper, therefore, is an attempt from 'situation analysis perspective' to have a bird's eye view of the impact and implication of covid pandemic over the tourism industry of Gandaki province with special focus on Pokhara by taking three vital variables; investment, employment and volume of transactions. It's a kind of 'situation analysis research' based mainly on secondary information backed up by sufficient primary data and information. The two main impacts of covid-19 over the tourism domain of Pokhara and its vicinity seem to be the shutdown of substantial numbers of hospitality businesses and the bulk loss of employment from tourism sector.
\end{abstract}

Keywords: Covid-19, impact, Pokhara, revive, tourism,

\section{INTRODUCTION}

Sylvia Browne, an American author, predicted a global epidemic in 2020 via her book named 'End of Days: Predictions and Prophecies about the End of the World' published in

(C) The Author, published by JRCC, Janapriya Multiple Campus. 
2008. Her prediction was for the global illness with severe attack on longs and bronchial tubes resisting all known treatments (Browne, 2008). Eventually, the prophecy turned into real with the advent of global pandemic of "covid-19". Novel Corona Virus (Covid-19), identified from Wuhan Province of China in December 2019 (WHO, 2021), engulfed even the super powers of the globe. The earliest report of a coronavirus infection was reported in the late 1920s when an acute respiratory infection of domesticated chickens emerged in North America (Estola, 1970). Researchers also identified the culprit behind the bronchial respiratory abnormality during common colds on human in 1965. Dorothy Hamre and John Rocknow at the University of Chicago got success to isolate and grow the virus in human kidney via tissue culture and designated it 229E (Knapp, 2020) and it was the first proven coronavirus to infect humans (Kahn \& McIntosh, 2005; Monto, 1984; Tyrrell \& Bynoe, 1965). Researchers gave its name coronavirus after its appearance as like of a crown.

It is reported that seven different coronaviruses can infect humans with varying lethality attribute. Four human coronavirus having mild symptoms like common cold and fever are HCoV-OC43, HCoV-HKU1, HCoV-229E AND HCoV-NL63. Other three human coronaviruses producing potentially severe symptoms are SARS-CoV (identified in China in 2002), MERS-CoV (identified in Saudi Arabia in 2012) and SARS-CoV-2 (identified in 2019). The ongoing coronavirus disease 2019, named covid-19 by World Health Organization in 11 February 2020, is basically a contagious disease caused by severe acute respiratory syndrome coronavirus 2 (SARS-CoV-2) and it was first isolated from three people with pneumonia connected to the cases of acute respiratory illness in Wuhan of China in December, 2019. Scientists and researchers have claimed that covid-19 is a mutated form of its previous cousins, SARS and MERS, and is proved to be more lethal (Knapp, 2020).

According to World Health Organization, more than 200 countries (Asia with the highest impact rate and middle East as well as Africa with the lowest impact rate) are being affected now by covid-19 with more than 4.17 million cases of death globally as of $26^{\text {th }}$ July, 2021 (WHO, 2021) that counts $2.14 \%$ of confirmed cases. Nepal is also affected badly due to this pandemic and its rate is $1.42 \%$ with 9,758 death cases till 26 July, 2021 (MoHP-GoN, 2021; WHO, 2021). The entire world terrified by it and the World Health Organization [WHO] declared global emergency. Scientists have tried their best day and night to find out the vaccine against covid-19 for its remedy permanently. The WHO also kept Nepal in one of the highly prone areas for this virus. As per WHO report, more than 3.8 billion people have already vaccinated till $26^{\text {th }}$ July 2021 globally. 
Tourism industry as such is a travel business and associated with movement of people. It also involves high level of host guest interactions and encounters. As per Mathieson and Wall (1982), tourism is basically a movement of people away from their usual place of residence for short period of time to destinations which cater various needs and necessities of travelers who also involve in various activities in the destination. Hence the industry highly associated with people's movement, interactions and activities cannot remain away from the influences of natural disasters, conflicts, pandemics like SARS, MERS \& covid-19. Rather, it is one of the highly suffered industries everywhere from such pandemonium, be it developed or developing countries like Nepal. Consequently, the promotional 'Visit Nepal Year 2020' campaign initiated by Ministry of Culture, Tourism and Civil Aviation (MoCTCA) of Nepal disturbed severely. The Government of Nepal also imposed restriction and national lockdown since March 24, 2020 (MoHP-GoN, 2021) that paralyzed almost all facets of the national mechanism. The life affected harshly when the economy suddenly dropped down to $2.27 \%$ from $6.5 \%$ (CBS, 2021) due to lockdown and restriction. The pandemic ruined some sectors like education, transportation, tourism and hospitality very severely compared to others. The tourism industry of Pokhara is also affected heavily and reached to complete cessation due to covid-19.

In pre-covid situation, travel and tourism was unquestionably the biggest global industry of $21^{\text {st }}$ century. Its contribution was $10.4 \%$ GDP in 2019 that accounted for US\$ 9.17 trillion and 334 million (10\%) jobs globally. After the covid-19 pandemic, the GDP contribution of global tourism industry plummeted to $5.5 \%$ with a loss of almost US\$ 4.5 trillion revenue and 61.6 million jobs around the globe (WTTC, 2021). Nepal received 11,97,191 tourists in 2019 that contributed NPR 247.5 billion (6.7\%) for national economy by generating more than 1 million jobs that accounts for $6.9 \%$ of total national employment. In spite of being an ideal mountain tourist destination in global market as it has successfully conducted the mixture of many tourism activities like soft walking, hiking, mountain sightseeing, trekking, mountaineering, rural/village tourism, community based home-stay tourism, eco-tourism and adventure-sports tourism, the global pandemic heavily battered the tourism sector of Nepal also, mostly due to its heavy reliance on international market. Visitors' number dropped by $80 \%$ in 2020 causing $46.6 \%$ fall in national GDP contribution and loss of almost 2 lakhs jobs (MoCTCA, 2020).

In the spectrum of Nepalese tourism, Gandaki Province remains at the crux as it is centrally located and blessed with immense potentialities for tourism development and growth. The diverse topography, unique combination of bio-diversities, typical cultural richness and 
mesmerizing natural beauties are some of the tourism assets of this province. On top of this, Pokhara - a tourism capital of the country - is the headquarters of Gandaki province. Pokhara as such is a melting bowl (Parajuli, 2004) of different caste, culture and religion and tourism is one of the drivers to keep this destination a lively city (Sharma, 2012).

Despite of being a major tourism destination of Nepal, Pokhara also became a victim of covid-19 pandemic. Pokhara has investment of NPR 500 billion in tourism and hospitality sectors. The city received 480,000 tourists in 2019 generating 75,000 jobs for skilled and semi-skilled people (PMC, 2020). Pokhara Metropolitan City estimated to have NPR 2.123 billion transaction monthly before covid-19 pandemic and the pandemic completely halted the industry triggering a heavy loss of NPR 5.8 billion (39\% of total PMC loss) during first lock down period of 24 $4^{\text {th }}$ March, 2020 to $14^{\text {th }}$ June, 2020 (UPC-PMC, 2077). This more than 25 billion's tourism industry is the leading industry of Pokhara metropolitan with a second biggest share of $25.4 \%$ following the wholesale/retail business which covers $26.4 \%$ of total volume of metropolitan transactions (UPC-PMC, 2077). The aim of this paper is to have a bird's eye view on the impact and implication of COVID-19 pandemic over the tourism industry in Pokhara

\section{DATA AND METHODS}

This paper is based on primary data as well as secondary information published by different international, national and local level organizations such as United Nations World Tourism Organization (UNWTO), World Travel and Tourism Council (WTTC), World Health Organization (WHO), Ministry of Culture, Tourism and Civil Aviation (MoCTCA), Ministry of Health and Population (MoHP), Nepal Tourism Board (NTB), Central Bureau of Statistics (CBS), Provincial Level Ministry of Industry, Tourism, Forestry and Environment (MoITFE) of Gandaki, Pokhara Metropolitan City (PMC), Pokhara Tourism Council (PTC) along with other relevant publications. The first hand data and information regarding socio-economic implications were collected from the focus group discussions and personal interview with the selected key informants, mostly leaders, of tourism employee associations and entrepreneurs' organizations of tourism and hospitality; and the information were incorporated whenever the secondary information appeared insufficient to justify and analyze further.

Pokhara, the headquarters of Gandaki Province of Nepal, is also called the tourism capital of the country due to its diverse touristic appeal. The confluence of different caste, culture, religion, nature, topography and climatic condition has made Pokhara, and at large the entire 
Gandaki Province, an important tourist destination of the country with a number of tourism activities from boating to rafting, paragliding to sky diving, trekking to mountaineering, cave stay to night life, cultural tour to jungle safari, canyoning to bungee, biking to off-road drive, village-hospitality to wilderness-hostility etc. to name a few (Sharma, 2010). In spite of all these possessions, the wave of covid-19 heavily crushed this destination and left it standstill during the pandemic. Therefore, Gandaki Province at large and Pokhara specifically selected for study area for this paper. Methodologically, the study is mainly based on quantitative approach with blended mode of descriptive methods to analyze and synthesize the impact of corona virus on three important segments of tourism sectors in the destination: investment, employment and transactions. The industry is mainly divided into three categories. One category represents the tourism business enterprises which are registered mainly to provide tourism service. The other category is the fragment of business enterprises whose main aim is not to provide tourism service but entirely thrive on tourism and the third category represents tourism products (natural / manmade) of the destination Pokhara.

\section{RESULTS AND DISCUSION}

\section{Impact of Covid-19 on Tourism in Nepal}

Nepal is a small but beautiful scenic country with a number of world famous eight thousanders including the tallest peak in the world Mt. Everest. The country possesses incomparable geo, bio, cultural and climatic diversities (Gurung, 2011). These diversities are the assets for the tourism industry of Nepal. Hence, the tourism industry revolves around nature, culture and adventure in Nepalese context. In spite of its richness, the country has faced undulating tourism growth due to various internal and external incidents and occurrences. Major internal obstacles for tourism growth in Nepal are (Maiost) insurgency, calamities such as dreadful earthquake of 2015 and political instability whereas problems like terrorism, diseases like SARS, MERS etc in source market and global phenomenon like coronavirus have also been the main problems for uneven inflow. However, last couple of years had been remarkable for Nepalese tourism industry that marked 1 million inflow of tourists. Nepal received 1.173 million tourists in 2018 which reached to 1.197 million in 2019 (MoCTCA, 2020). The industry contributed NPR 247.5 billion (6.7\%) to the national economy generating more than 1 million jobs (6.9\% of total employment) (WTTC, 2021). Tourism is one of the highly affected sectors of covid-19 pandemic in Nepal as well. In 2020, Nepal just welcomed 
230,085 international visitors ( $80 \%$ less than previous year) which is the lowest number since 1990. This $80 \%$ drop down of visitors in 2020 caused $20 \%$ job (more than 2 lakhs) loss and contributed only $3.6 \%$ GDP (46.6\% less) to the national economy due to the effect of coronavirus. The international visitors' spending was NPR 96 billion which happens to be $30.1 \%$ contribution to the total national exports in 2019 but it dropped by almost $70 \%$ in 2020 and reached to NPR 29.4 billion in 2020 (MoCTCA, 2020; WTTC, 2021).

\section{Impact of Covid-19 on Tourism in Pokhara}

Nepal is profoundly an idyllic mountain tourism destination for the reason that it offers a varieties of tourism activities such as hiking, trekking, mountaineering, sightseeing, bird watching, homestay, eco-trek/lodge, high-altitude sports and adventures etc. Among the various prime tourist locations of Nepal, Gandaki Province is centrally located in the country and cosmically blessed and naturally gifted area for tourism (Chauhan, 2004; Upadhayaya \& Khatiwada, 2012).

Gandaki Province has drawn the attraction of visitors with its diverse landscape, unique bio-diversities, culturally rich and naturally beautiful resources. Pokhara is the hotspot for tourism in Gandaki Province and it's also the capital of the Province. A prominent Geologist Tony Hagen noted about the natural beauty of Pokhara and its surrounding like as "Pokhara area shows the greatest contrasts in landscape...Pokhara is certainly one of the most extraordinary and most beautiful places in the whole world" (Gurung, 2011, p. 124). Those historical remarks have proved the beauty of Pokhara and its surrounding to develop as a tourism city in Nepal.

Pokhara and its vicinity was not so popular before the successful ascent of Mt. Annapurna ( $8091 \mathrm{~m}$ ) by a French citizen Maurice Herzog and his team in June 3, 1950. It became 'Hippies' Favorite Freak Zone' in the decade of 1960s till early 70s and later became desired destination for mountaineering also in the decade of 80s (Sharma, 2012). Establishment of tourist information center in Pokhara in 1961, the trekking expedition of Jimmy Robert's team (Col of East India Company) in 1966 (Upreti \& Upadhayaya, 2013) and the establishment of Fishtail Lodge, the heritage of hospitality, in the late 60 s have also played significant role to develop professional tourism in Pokhara.

Pokhara, the biggest metropolitan city of Nepal, with a size of 464.24 sq.km. is politically divided into 33 wards. Its current population is almost 6 lakhs which is growing at the rate of $5.46 \%$ - the highest growth rate in national context (PMC, 2021). Pokhara is also known as a land of unity with diversity of language, religion, ethnicity, tradition, norms, values, behaviors 
and culture of Aryan and Mangolian communities (Parajuli, 2004) who show exemplary harmony and mutual respect for co-existence. The cross-cultural interaction with the elements of such a diverse society is a strong intrinsic motivational aspect for many tourists in the travel process (Sharma, 2010). Situated at the elevation of almost 800m above sea, Pokhara valley possesses high potentiality for tourism, agriculture and hydroelectricity as sources of the prosperity (Adhikari \& Seddon, 2002). The features like unique landscape, biodiversity, shining mountains, people and culture, caves, blue lakes and rivers etc. are common in the periphery of Pokhara within the Gandaki Province. There are even so many scenic villages in the rural settlement of this province and could be developed as attractive tourist point. But in fact, due to the lack of alternate activities or limited man made physical tourism resources in the rural areas, tourism activities are limited within core city area (Upadhayaya \& Khatiwada, 2012).

Pokhara, a capital of tourism, is a beautiful city with the amalgamation of hypnotizing sceneries, enigmatic rivers and falls, crystal clear lakes, high looming cascading white mountains, green hills full of birds and butterflies, mysterious caves, diverse culture, museums, temples and monuments. Once hippies' tranquility zone has now become famous for aerial adventurous sporting activities like paragliding, sky diving, ultra-flight, hot air ballooning, bungee and zip-line (Sharma, 2008). Pokhara is equally famous among tourists from sightseeing to pilgrimage, trekking to mountaineering, canyoning to rock climbing, boating to white water rafting. The climatically pleasant zone, Pokhara, really provides a touristic appeal to every visitor in this destination and so has been a favorite hang-out destination for domestic tourists as well.

\section{Table 1}

Tourist Arrivals in Nepal, Pokhara and ACA

\begin{tabular}{lllllll}
\hline Year & $\begin{array}{l}\text { Tourists in } \\
\text { Nepal }\end{array}$ & $\begin{array}{l}\text { Growth } \\
(\%)\end{array}$ & $\begin{array}{l}\text { Tourists in } \\
\text { Pokhara }\end{array}$ & $\begin{array}{l}\text { Share of } \\
\text { Pokhara }\end{array}$ & $\begin{array}{l}\text { Tourists in } \\
\text { ACA }\end{array}$ & $\begin{array}{l}\text { Share of ACA } \\
\text { in Pokhara }\end{array}$ \\
\hline 2008 & 500,277 & $-5.00 \%$ & 186,643 & $37.31 \%$ & 72,175 & $38.67 \%$ \\
2009 & 509,956 & $1.90 \%$ & 203,527 & $39.91 \%$ & 79,896 & $39.26 \%$ \\
2010 & 602,867 & $18.30 \%$ & 230,799 & $38.28 \%$ & 90,161 & $39.06 \%$ \\
2011 & 736,215 & $44.37 \%$ & 283442.78 & $* 38.50 \%$ & 101,908 & $35.95 \%$ \\
2012 & 803,092 & $9.08 \%$ & 309190.42 & $* 38.50 \%$ & 106,499 & $34.44 \%$ \\
2013 & 797,616 & $-0.68 \%$ & 307082.16 & $* 38.50 \%$ & 116,120 & $37.81 \%$ \\
2014 & 790,118 & $-0.94 \%$ & 304195.43 & $* 38.50 \%$ & 129,624 & $42.61 \%$ \\
2015 & 538,970 & $-31.79 \%$ & 207503.45 & $* 38.50 \%$ & 78,930 & $38.04 \%$ \\
\hline
\end{tabular}




\begin{tabular}{lllllll}
\hline 2016 & 753,002 & $39.71 \%$ & 289905.77 & $* 38.50 \%$ & 114,507 & $39.50 \%$ \\
2017 & 940,218 & $24.86 \%$ & 361983.93 & $* 38.50 \%$ & 159,560 & $44.08 \%$ \\
2018 & $1,173,072$ & $24.77 \%$ & 451632.72 & $* 38.50 \%$ & 172,720 & $38.24 \%$ \\
2019 & $1,197,191$ & $2.06 \%$ & 460918.54 & $* 38.50 \%$ & 181,746 & $39.43 \%$ \\
2020 & 230,085 & $-80.78 \%$ & 88582.725 & $* 38.50 \%$ & 18,796 & $21.22 \%$ \\
\hline
\end{tabular}

Sources: MoCTCA,2018; Tourism office, Pokhara, 2015 and ACAP Office, Pokhara, 2020;

* Calculation on the basis of past three-years (2008-10) average percentage

It is estimated from the previous findings that about 10 lakhs tourists visited Pokhara in 2019, international tourists represent almost $40 \%$ of total (more than 4 lakhs) whereas the share of domestic visitors is also significant with around 60\% (around 6 lakhs) (UPC-PMC, 2077). The figure also shows that Pokhara and its vicinity receive almost $39 \%$ tourists who come to Nepal. Among them around 40\% (five-year 2015-19 average) go to Annapurna Area mostly for trekking and hiking. Tourism has become a part and parcel of the people living in Annapurna region. One can see a huge economic transformation in this region due to tourism. But covid-19 battered entire tourism spectrum very badly and dropped international visitors' number by $73 \%$ globally. Tourism and hospitality industry of Nepal slumped heavily due to covid pandemic with more than $80 \%$ shrink in 2020 , which is higher than the global figure. This unusual drop down effect of tourists' number induced tourism activities down to almost halt. Therefore, the aim of this paper is to analyze the impact of covid-19 on three important variables of this industry; investment, income/transactions and employment with special focus on Pokhara and its vicinity.

The entire tourism industry of Nepal with almost NRs 1.6 trillion's investment is in jeopardy due to the pandemic of covid-19. It is also estimated that the industry has suffered almost NRs 10 billion every month (MoCTCA, 2020). As per the report of Urban Planning Commission of Pokhara Metropolis, tourism sector is one of the highest sufferers of covid-19 pandemic though the figures in some sectors seem highly controversial and based on unrealistic and unscientific conjectures. Based on this report, Pokhara periphery alone has investment of about NRs 500 billion on tourism and hospitality industry. Due to the ongoing pandemic, the industry has been losing at the rate of NRs 2.123 billion per month since the first lockdown in 24 ${ }^{\text {th }}$ March, 2020 (UPC-PMC, 2077).

During pre-covid situation, the total contribution (direct, indirect \& induced) of tourism industry in terms of employment was 75,000 jobs including 19,489 direct employments which is substantially important and stands second in size (18.80\%) after wholesale and retail business in 2019 in Pokhara as per the report published by Pokhara Metropolis (PMC, 2020). In case 
of transactions, it possesses $25.4 \%$ (NRs 25.477 billion per annum) of the total volume of the Metropolis against the highest volume of $26.4 \%$ of wholesale/retail business. The report also says that Pokhara Metropolis has been incurring monthly loss of NRs 5 billion 438.1 million due to the pandemic thereby having the highest share (i.e 39\% ) of total metropolitan loss is from tourism and hospitality industry of NRs 2 billion 123 million (PMC, 2020). Tourism and hospitality sector is the one of a few sectors which is in the top list of highest sufferer (almost $100 \%$ ) from the pandemic of covid-19 in Pokhara and periphery.

\section{Table 2}

Tourism, Investment, Contribution \& Loss in Pokhara (base year 2019)

\begin{tabular}{|c|c|c|c|c|}
\hline Destination & $\begin{array}{l}\text { Total } \\
\text { investment }\end{array}$ & $\begin{array}{l}\text { International } \\
\text { tourists arrivals }\end{array}$ & $\begin{array}{l}\text { Direct } \\
\text { employment }\end{array}$ & $\begin{array}{l}\text { Loss per month due to } \\
\text { covid-19 }\end{array}$ \\
\hline Nepal & NRs 1.6 trillion & $1,197,191$ & 427,000 jobs & NRs 10 billion \\
\hline Pokhara & NRs 500 billion & $460,918 *$ & 75,000 jobs & NRs 2.123 billion \\
\hline
\end{tabular}

Source: MoCTCA, 2020; NTB, 2020; MoITFE, 2077 \& * C/F Table: 1

There are a number of enterprises which entirely depend and thrive on tourism - be it domestic or international in Pokhara. Some major sectors which comprise the entire tourism industry of the region are hotel, restaurant \& bar, travel \& trekking agencies, paragliding, altralight, rafting, trekking equipment, tourist vehicles, money changers, book shops, boutique and curio shops, boat service, embroidery etc. The covid pandemic has pushed the investment of these sectors to the brink. It is a shocking fact as per the key informants that almost $30 \%$ of them have already left their business in Pokhara deserting their lifetime investment. Similarly, 40\% of them have padlocked their property and yet have survived somehow waiting desperately a better tomorrow whereas remaining $30 \%$ have sporadic engagement in business.

\section{Table 3}

Major Tourism Businesses in Pokhara

\begin{tabular}{lllll}
\hline Business sectors & Number & $\begin{array}{l}\text { Investment } \\
\text { (NRs in Crore) }\end{array}$ & Employment & $\begin{array}{l}\text { Monthly transaction } \\
\text { (Rs. in Lakhs) }\end{array}$ \\
\hline Tourist standard Hotel & 700 & 12500.00 & 12,928 & 5670 \\
Trekking Agency & 159 & 74.97 & 1272 & 131 \\
Travel Agency & 181 & 265.85 & 1012 & 130 \\
Restaurant \& Bar & 100 & 400.00 & 1500 & 876 \\
Paragliding & 65 & 65.00 & 1000 & 375 \\
Ultra-light/ Power & 3 & 24.00 & 105 & 943 \\
Glider & & & & \\
\hline
\end{tabular}




\begin{tabular}{lllll}
\hline Tourist Vehicles & 86 & 64.00 & 653 & 582 \\
Rafting Agency & 12 & 12.00 & 180 & 42 \\
Bungee / Jip Flyer & 2 & 20.00 & 42 & 34 \\
Hot Balloon & 1 & 10.00 & 20 & 4 \\
Total & 1309 & 13435.8 & 18712 & 8787 \\
\hline
\end{tabular}

Source: Field Survey \& MoITFE, 2077

In Pokhara, there are almost eleven types of organizations which entirely thrive on tourism and hospitality business and have registered as tourism related service provider in company registrar's office. The total number of these type of business enterprises is 1,309. Their investment is about NRs 134.358 billion and they have generated 18,712 direct employments for the destination. An estimation shows that the volume of transactions of these industries in a month is NRs 878.7 million. The covid-19 has completely pushed them to the deadlock and their business volume is almost nil and hence these industries are bearing a huge loss of almost NRs 30 million every day.

\section{Table 4}

Status of Tourism Induced Business in Pokhara

\begin{tabular}{lllll}
\hline Sectors & Number & $\begin{array}{l}\text { Investment } \\
\text { (Rs in Crores) }\end{array}$ & Employment & $\begin{array}{l}\text { Monthly transaction } \\
\text { (Rs. in Lakhs) }\end{array}$ \\
\hline Spa Centers & 63 & 20.25 & 378 & 142 \\
Tourist Cab/Taxi & 200 & 30.00 & 204 & 120 \\
Trekking Equipment Shop & 95 & 90.00 & 285 & 570 \\
Embroidery \& Garment & 75 & 55.00 & 375 & 22.5 \\
Tourists Book Shop & 15 & 10.40 & 200 & 72.9 \\
Boats in Fewa & 761 & 16.16 & 357 & 30.9 \\
Boats in Begnas & 250 & 5.00 & 151 & 468 \\
Money Changer & 42 & 10.50 & 84 & 1232 \\
Total & 1501 & 237.31 & 2034 & 2658.3 \\
\hline
\end{tabular}

Source: Field Survey, 2078 \& MoITFE, 2077

There are different types of tourism-induced services or business in Pokhara. Among them, the above mentioned (Table 4) eight organizations highly depend on tourism. Although they are not directly registered as a tourism company, their business is highly associated with tourists and visitors in the destination and hence they are addressed as tourism-induced business. They are spa, tourist cab, trekking equipment, embroidery \& garment, curio \& souvenir shops, book shop, boat service, and money changer are notable ones. They are 1501 in numbers. They also have substantial investment in their business of NRs 2.373 billion. Their contribution 
for employment is also significant. In total, 2034 people are found directly involved in these types business in Pokhara. The volume of transactions of these industries every day before covid-19 pandemic was meaningfully sizable. Its monthly volume used to exceed NRs 265.83 million before pandemic in tourist season. They are also one of the sufferers due to the closure triggered by pandemic situation and hence more than two thousand people are not only being jobless in this segment but they are also bearing a loss of about Rs 8.861 million every day (Rs 265.83 million monthly) during the entire lockdown periods. The investment of these type of service enterprises of more than two billion is also in peril.

Pokhara is not only bestowed with a number of natural gifts which are amazing tourism products but also has a few but specially alluring products and places for the person who visits Pokhara. They are museums, caves, towers, temples and monasteries. Some places like temples and monasteries do not have any entry fee for visitors and hence excluded in this study while analyzing the financial loss though they also have suffered heavily due to the lockdown protocol.

\section{Table 5}

Income \& Employment generation from tourism products in Pokhara

\begin{tabular}{lllll}
\hline $\begin{array}{l}\text { Products \& } \\
\text { attractions }\end{array}$ & $\begin{array}{l}\text { No. of visitors } \\
\text { (annual) }\end{array}$ & $\begin{array}{l}\text { Annual income } \\
\text { (Rs.) }\end{array}$ & $\begin{array}{l}\text { Direct } \\
\text { employment }\end{array}$ & Remarks \\
\hline Mountain Museum & 300,000 & $27,500,000$ & 23 persons & \\
Cultural Museum & 10,148 & $1,455,868$ & 10 persons & \\
Mahendra Cave & 408,000 & $20,413,000$ & 46 persons & Including School staffs \\
David's Falls & 691,100 & $22,842,000$ & 37 persons & Including School staffs \\
Gupteshwor Cave & 441,432 & $25,233,000$ & 21 persons & Supporting for 50 \\
& & & & students full boarding \\
Total & - & $97,443,868$ & 137 persons & \\
\hline
\end{tabular}

Source: Field Survey, 2078 \& MoITFE, 2077

The museums, caves and towers of Pokhara and its vicinity had earning record of more than 97.443 million per annum in pre-pandemic situation. Unknowingly these tourism products had provided direct job opportunity for 137 persons. Other indirect but very important contribution to note here is that the fund collection from Mahendra Cave is used to pay the salary of teachers and staffs who work in Bindhaybasini school of Batulechour. Similarly, David's Fall provides fund to the Chhorepatan School to incur monthly remuneration of teachers and staffs working there. Therefore, hundreds of other people are direct beneficiaries of the tourism revenue collected from visitors in this places. The credit of their employment 
basically goes to tourism obviously. Likewise, the revenue collected from Gupteswor Cave is also used to incur the boarding (lodging/fooding) expenses of 50 batuk (sanskrit students) who live and study in Guputeswor Ashram. Though museums and caves do not only depend on foreign visitors and are visited by significant numbers of local people, yet they are also in a complete pause due to the health protocol, locally enforced restrictions of entry by local authority during lockdown period.

\section{CONCLUSION}

The study shows that the covid-19 pandemic has terribly pushed the investment of entire tourism sector of Pokhara destination to the brink. Almost the industry has been losing more than Rs 34 million every day from only the companies / firms covered for analysis in this paper thereby losing more than Rs 70 million from the entire tourism industry of the destination every day during lockdown period of covid-19 pandemic. A huge segment of employees in this industry became complete jobless during lockdown period that put their life in hard situation even to survive. The two main impacts of covid-19 over the tourism domain of Pokhara seem to be the shutdown of substantial numbers of hospitality businesses and the bulk loss of employment from tourism sector.

In spite of the huge loss in investment and revenues, some of the associations of stakeholders also tried the best from their level to sustain and revive the tourism industry of Pokhara duding on-covid period. Some hotels and restaurants supported employees by making partial payment even in no-job time during lockdown period. Trekking Agencies' Association of Nepal (TAAN) Pokhara, Nepal Association of Tour \& Travel Agents (NATTA) Pokhara and Restaurant and Bar Association of Nepal (REBAN) Pokhara also distributed some packets of basic utility goods and kinds to the informal and freelance tourism workers, tour/trek guides, supporting staffs and boat sailors of Fewa Lake catchment. Pokhara Metropolitan City has also shown deep concern about the survival of tourism in Pokhara and hence has increased the ceiling of budget from Rs 24.6 million of past year to Rs 265 million in current year merely for tourism plan and development in Pokhara and vicinity (PMC, 2021). Albeit there are some implementation issues, the provincial as well as the federal government of Nepal have also devised some financial schemes of soft loan to the tourism entrepreneurs, rebate in taxation as well as in the company renew charge. 


\section{REFERENCES}

Adhikari, J., \& Seddon, D. (2002). Pokhara: Biography of a town. Mandala Book Point.

Browne, S. (2008). End of days: Predictions and prophecies about the end of the world. Penguin Group.

CBS. (2021). Key indicators. Central Bureau of Statistics, National Planning Commission, Government of Nepal. Retrieved July 7, 2021, from https://cbs.gov.np

Chauhan, Y. S. (2004). Eco-tourism in Nepal. Kaliinga Publications.

Estola, T. (1970). Coronaviruses, a new group of animal RNA viruses. Avian diseaseses, 14(2), 330-336. Retrieved from https://www.jstor.org/stable/1588476

Gurung, H. (2011). Maile dekheko Nepal. Himal Kitab Pvt. Ltd.

Kahn, J. S., \& McIntosh, K. (2005). History and recent advances in coronovirus discovery. The Pediatric Infectious Disease Journal, 24 (11), 223-227.

Khatiwada, S. K. (Ed.). (2007). Tourism product exploration and development in Pokhara region. Proceedings of the Master Workshop. Visit Pokhara Year - 2007.

Khatiwada, S. K., \& Kshetri, Y. B. (Eds.). (2004). Pokhara Tourism Mirror, 1. Pokhara Tourism Council.

Knapp, A. (2020). The secret history of the fist coronavirus. Retrieved July 18, 2021, from Forbes: https:/www.forbes.com/sites/alexknapp/2020/04/11/the-secret-history-of-thefirst-coronavirus-229e/?sh=147ee03171d6

Mathieson, A., \& Wall, G. (1982). Tourism: Economic, physical and social impacts. Longman.

MoCTCA. (2020). Nepal tourism statistics 2020. Ministry of Culture, Tourism and Civil Aviation (MoCTCA), Government of Nepal.

MoHP-GoN. (2021). Covid dashboard. Ministry of Health and Popuation, Government of Nepal. Retrieved July 5, 2021, from https://covid19.mohp.gov.np

MoITFE. (2077). Impact assessment of Covid-19 on tourism sector and revival plan. Ministry of Industry, Tourism, Forestry and Environment, Gandaki Province, Nepal.

Monto, A. (1984). Coronaviruses. In a. Evans (Ed.), Viral infections of human: Epidemiology and control (pp. 151-165). Springer.

Parajuli, B. K. (2004). A glimpse on social and cultural configuration of Pokhara city. Pokhara Tourism Mirror, 26-28.

PMC. (2020). Tourism revival strategic plan 2078-82. Pokhara Metropolitan City (PMC).

PMC. (2021). Pokhara Metropolitan city, Gandaki Province. Retrieved July 28, 2021, from https://www.pokharamun.gov.np 
Sharma, R. (2008). Prospects in Pokhara: Sports tourism. Pokhara Tourism Mirror 1, 42-43.

Sharma, R. (2010). Tourism and lifestyle: Analysis of cross-cultural interface. Himalayan Journal of Sociology and Anthropology, 4, 206-223. doi: https://doi.org/10.3126/hjsa. v4i0.4675

Sharma, R. (2012). Tourism, socio-cultural transformation and need of destination rebranding: A case of Pokhara. Pokhara Management Review, 3, 67-74.

Sharma, R. (2020). Sociology of tourism : Shifting paradigm from nostalgia to happiness. Journal of Tourism \& Hospitality Education, 10, 90-107. doi:https://doi.org/10.3126/ jthe.v10i0.28762

Tyrrell, D., \& Bynoe, M. (1965). Cultivation of a novel type of common-cold virus in organ cultures. British Medical Journal, 1(5448), 1467-1470.

UNWTO. (2020). International tourism highlights 2020 edition. United Nations World Tourism Organization.

UNWTO. (2021). World tourism barometer and statistical annex. United Nations World Tourism Organization (UNWTO). Retrieved July 7, 2021, from https://www.e-unwto. org/doi/epdf/10.18111/wtobarometereng.2021.19.1.3

Upadhayaya, P. K., \& Khatiwada, S. K. (2012). Facing the challenges of sustainable peace and prosperity in tourism of Pokhara. Proceeding of a Regional Conference. Pokhara Tourism Council and the National Center of Competence in Research (NCCR) NorthSouth.

UPC-PMC. (2077). Rapid assessment of Covid-19 impact on local economy of Pokhara Metropolitan city and a study of revival strategy. Urban Planning Commission - Pokhara Metropolitan City (UPC-PMC).

Upreti, B. R., \& Upadhayaya, P. K. (2013). Tourism in Pokhara: Nepal's pride and means for peace and prosperity. In B. R. Upreti, P. K. Upadhayaya, \& T. R. Sapkota (Eds.), Tourism in Pokhara: Issues, Trends and Future Prospects for Peace and Prosperity (pp. 1-25). Kathmandu: Pokhara Tourism Council (PTC), Swiss Natinal Centre of Competence in Research (NCCR) North-South and Nepal Center for Contemporary Research (NCCR), Kathmandu.

WHO. (2021, July 28). Coronavirus disease (COVID-19) pandemic. Retrieved from World Health Organization: https://www.who.int/emergencies/diseases/novelcoronavirus-2019

WTTC. (2020). Travel and tourism global economic impact \& trends. World Travel and 
Tourism Council.

WTTC. (2021). Travel and tourism economic impact 2021. World Travel and Tourism Council (WTTC). Retrieved July 7, 2021, from https://wttc.org/Portals/0/Documents/ Reports/2021/Globa1\%20Economic\%20Impact\%20and\%20Trends\%202021. pdf?ver=2021-07-01-114957-177. 